\title{
A HISTORY OF AMERICA IN 100 MAPS
}

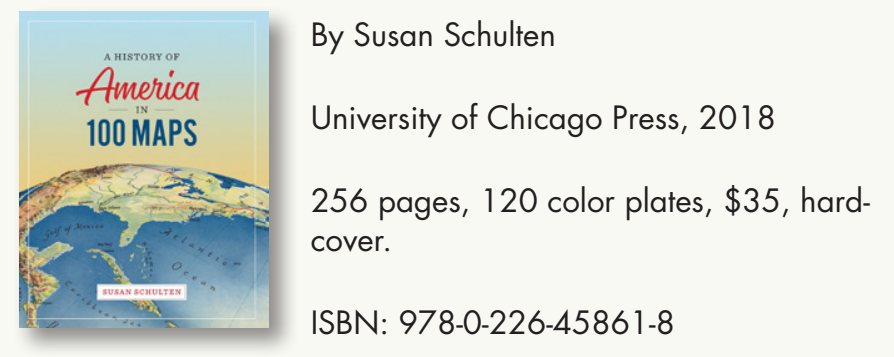

Review by: Jörn Seemann, Ball State University

Richly illustrated coffee table books about maps have become quite popular in recent years. Anyone interested in cartography can learn about the history of the world mapby-map while sitting down with the History of the World Map by Map (Smithsonian Institution 2018), "go on a guided tour through the world's most incredible maps" aboard All Over the Map: A Cartographic Odyssey (Mason and Miller 2018, back cover), explore odd and unconventional maps for the "cartographically curious" through The Curious Map Book (Baynes-Williams 2015, back cover), or get insights into historic cartographic myths and blunders from The Phantom Atlas: The Greatest Myths, Blunders and Lies on Maps (Brooke-Hitching 2018), just to mention a few examples. All of these books aim to narrate history visually through cartography-inviting their audiences to read between the lines of a map in order "to tease out new meanings, hidden agendas, and contrasting world views" (Harley 1990, 4).

Among the myriad publications of this kind are atlases and map compilations that focus on what is loosely called America, but is in practice more narrowly interpreted as North America or even just the United States of America. $A$ History of America in 100 Maps is one of the most recent of these works, conceptualizing US history through visual narratives. The author, Susan Schulten, is a historian at the University of Denver and a specialist on nineteenth- and twentieth-century United States history. Her particular interest in the history of maps has resulted in a considerable number of publications, including two very successful and highly readable books: one, The Geographical Imagination in America (2001), on the place of geographical imagination and of maps in popular culture, politics, and education; the other, Mapping the Nation (2012), on the interface between thematic mapmaking and national identity in nineteenth-century America.
The idea of telling American cartographic history is not new. Almost four decades ago, the renowned surgeon, writer, and map historian Simon Schwartz, and the map librarian Ralph Ehrenberg, published The Mapping of America (1980). The bulky, 363-page volume included more than 300 black-and-white and color plates and more than 200 illustrations to "present a detailed analytical history of the mapping of North America ... [and] demonstrate that a map is often more than a visual record of boundaries" (Schwartz and Ehrenberg 1980, 9). More recently, Mapping America: Exploring a Continent presented more than 120 color maps tracing "the formation and development of the US over 500 years, from the time of the early European colonies through to the densely developed and influential country it is today" (Howells and McCorquodale 2010, 9).

So what's new about Schulten's book? At first glance, the author uses the same strategy as the earlier publications I have noted. She compartmentalizes the past by defining relatively distinct periods in US history, from "Contact and Discovery" (1490-1600) and "Early Settlement and the Northwest Passage" (1600-1700), to "Between War and Abundance" (1940-1962) and "An Unsettled Peace" (1962-2001). For each of the nine chapters, Schulten selects about a dozen maps that testify to moments or episodes that marked the country's history. The one hundred maps-covering a variety of topics, places, and contextswere chosen from a number of prestigious libraries and map collections, with an emphasis on material from the British Library. Each map is accompanied by text that provides background information and contextualizes each specific historical moment. The full extent of each map is shown at reduced scale, but some have larger-scale detail views provided as well.

In her own words, Schulten intends to give "a visual tour of American history through maps, one that searches the main roads as well as the back-alleys of the past" (8), and the collection can indeed be divided into "main road" and "back-alley" elements. The "main road" examples are well known and familiar maps, whose historical significance makes their inclusion in any work on American cartographic history seem obligatory. Among these iconic maps is Waldseemüller's Universalis Cosmographia from 1507 (16-19). This is the map upon which the name "America" 
appeared for the first time, albeit only discreetly printed in the lower-left corner, in an area that today is part of Argentina. It is quite common for historians to describe this particular map as America's "birth certificate," or to describe its era as one in which the continent was "discovered"- despite its having been inhabited by several million people for a considerable period of time-but the use of these terms raises significant issues. While Schulten briefly discusses some of these problems in her Introduction, she misses several opportunities to engage them more deeply in the entries on individual maps.

Other "main road" examples include graphical statements of the exploration history of the American West: the map of the Lewis and Clark Expedition (114-115), and John Wesley Powell's map of the arid regions in the west (162163). Powell's map proposed a system of land settlement based on watersheds and moisture regimes rather than the established grid system of square townships. A copy of the famous 1812 "gerry-mander" map of the Essex South District in Massachusetts (116-117) and a thematic map of the United States (174-175) indicating the circa-1914 status of women's suffrage-full, partial, or no-stand out as political statements in American history.

The "back-alley" maps are lesser known, forgotten, or ephemeral maps that, nevertheless, are important or fascinating pieces of US history. Examples are the young George Washington's hand-drawn map of the lands between Lake Erie and the Ohio River (circa 1754), showing French fortifications (84-85); a 1917 diagram of a typical line of battle during World War I with fire trenches, second lines, and no man's land (178-179); and Herb Ryman's 1953 bird's-eye view of Disneyland (226-227), used by Walt Disney to recruit potential sponsors for the amusement park project.

Schulten admits that it is impossible to tell a comprehensive cartographic history of America. Any attempt can only be "an eclectic and selective discussion of the many ways maps have been used in the past; to master and claim territory, defeat an enemy, advance a cause, investigate a problem, learn geography, advertise a destination, entertain an audience, or navigate terrain" (8). She is very careful with her selection of representative and illustrative examples, aiming not only to point out cultural differences and backgrounds, but cartographic diversity as well. On the one hand, the book includes maps that do not refer directly to the American territory, but that nonetheless had a strong impact on US history. For example, Schulten includes both a Portolan-style Dutch map of West Africa from around 1650 (50-51) and Malachy Postlethwayt's $A$ New and Correct Map of the Coast of Africa (1757, 74-75). These maps pinpoint different African nations and those places on the coast that were ports of departure for the slave trade to the Americas, and serve as exquisite pictorial documents of the tragedy of slavery. On the other hand, the book also illustrates cartographic diversity in that it allows a comparison between mapmaking techniques in different countries and the way map standards and symbolization changed over decades and centuries. The reader can compare Miera y Pacheco's almost baroque-style 1778 map of the discovered and demarcated lands in the American Southwest-which juxtaposes an almost excessive physiographic relief imaging with a drawing of the Papal chariot pulled by lions (88-89)—with Herman Moll's far more sober 1720 rendering of the North Parts of America Claimed by France, where "parts unknown" are simply left blank (70-71).

Each map in $A$ History of America in 100 Maps sparks curiosity and is worthy of detailed exploration, but I will restrict myself to a few extraordinary examples. Robarte Tindall's sketch of Chesapeake Bay (1608) is something of a cartographic ugly duckling-drawn with simple outlines and shapes in faded colors, but with a colorful ornamental frame. It contains only 21 place names (locations of indigenous villages), but emphasizes the meanders of the James and York Rivers in Virginia and provided the inaugural settlers of the Jamestown colony with a first notion of their environment (36-39). This map is an obscure cousin of John Smith's famous 1612 map of Virginia that highlighted the figure of the tribal chief Powhatan and the importance of indigenous informants for mapmaking. Smith discreetly indicated the limits of his geographical knowledge by a chain of Maltese cross symbols that surround Chesapeake Bay (40-41).

Another example of indigenous authorship is the transcribed copy of a deerskin map drawn by an unidentified indigenous leader for Francis Nicholson, who was governor of South Carolina between 1721 and 1725 (72-73). The original is long lost, but Nicholson had commissioned the fabrication of two copies, "most humbly Dedicated To His Royal Highness George Prince of Wales” (72). Initially, the drawing looks like a concept map or "a slightly confusing organizational chart" (72). However, a deeper reading reveals that the emphasis is not on physical distances, as it 
is in the case of Western maps, but on networks and relationships among and between Native American groups and European settlers. Thirteen irregular circular shapes in red represent different tribes and how they relate to each other and to "Charlestown," indicated as an angular grid of streets on the left side of the map.

Schulten also hints at gender and educational issues by including A Map of the United States (1818). This map was extracted from a copy of Catharine $M$. Cook's Book of Penmanship At Mr. Dunham's School, Windsor, Vermont found in the Osher Map Library, and is one of the few surviving examples of the geography exercises that were common at many schools for girls in the first half of the nineteenth century. Schulten writes that "[m] aps and geography were considered particularly appropriate material for girls, a 'useful' pathway to literacy and citizenship that also honed traditional feminine skills of 'accomplishment' such as painting or needlework" (118). Catharine Cook's schoolbook included drawings of the world and at least eight individual states, although Schulten reproduces only the map of the United States.

The book does not shy away from controversial issues such as racism. A sequence of three different maps exposes the segregation of ethnic groups in San Francisco, Chicago, and Philadelphia at the end of the nineteenth century. In San Francisco, the Official Map of Chinatown (1885), made in the style of a Sanborn fire insurance map by the Special Committee of the Board of Supervisors of the city, served as a political tool to demonize Chinese immigrants who, according to the map authors, were "living scarcely one degree' above waterfront rats, in unimaginably crowded conditions" (164). The map color-codes buildingshighlighting such locations as Chinese gambling and prostitution houses and "opium resorts." From Chicago, Nationality Map No.1 (1895), extracted from Hull's House Maps and Papers, reveals the ethnic configuration, segregation, and ghettoization of neighborhoods in that city. The Seventh Ward of Philadelphia map, by the scholar and civil rights activist W. E. B. Du Bois, not only points out racial segregation, but also the variations existing within predominantly African-American neighborhoods by identifying four classes of resident: the "middle classes and those above," the working people, the poor, and the "vicious and criminal" classes. These maps provide the context for two other maps: the Metropolitan Cleveland Security Map (1936) - a cartographic example of redlining (200201) —and the Afro American Travel Map (198-199), part of a 1942 travel guide issued by the Afro Travel Bureau in Baltimore, "list[ing] places where weary motorists would not be refused service because of their race" (199).

The most compelling examples among the one hundred maps are two simple sketches (216-217) from the diary of 15-year-old Michal Kraus, a Czech Holocaust survivor. One of the drawings shows parts of lower Austria between Melk and Gunskirchen. The Mauthausen concentration camp, where between 100,000 and 300,000 people were murdered in the period from August 1938 to May 1945, has a prominent position on the map. Michal added two drawings of the camp with barracks, wooded areas, and watchtowers. The second sketch documents the tortuous return route to his hometown, Náchod, where he found out that his mother had been killed in the camps. Michal began to write his diary about the horrors of the Holocaust in 1951, about the time he permanently settled in the United States.

A minor issue with this book, for me, is the dichotomy of news vs. history. At what point does the past become history? Where does a history of the United States shade into current events? Although the last chapter ends with Laura Kurgan's 2001 map Around Ground Zero (256257) - a pocket-sized foldout map of the site of the former World Trade Center that was created in remembrance of the 9/11 attacks-Schulten contemplates none of the more recent events and issues of the twenty-first century. Her Afterword addresses contemporary trends in cartography by giving the example of DeepMap, a software firm that provides mapping software for the autonomous vehicle industry, but she does not address other important challenges in cartography like deep mapping and the digital humanities, maps on a screen and in motion, and the constant frictions between mapmaking and GIS that have an impact on both history and the ways we conceive maps. Schulten might have usefully addressed the shift from paper to digital mapping, or the incredible speeds at which maps are often disseminated through social media, with pertinent map comparisons. In a recent article, for example, Anthony Robinson (2019) studied the Twitterbased distribution of a 2016 map of what voting patterns would have looked like had only women voted. The map went viral, provoking hundreds of replies and retweets, as well as the composition and dissemination of new variant maps derived from the original. This virtual map might have been juxtaposed with the 1883 "red-and-blue" map 
on popular vote by counties from Scribner's Statistical Atlas (156-157) Schulten had already included.

Despite its fantastic content, this volume is marred by the typography and the page layout. Although the unidentified sans-serif type is very pleasing, the 10-point (or smaller) font size used throughout is very hard to read and is a definite challenge for anyone's eyesight. As well, the text-image proportions on any given page can vary considerably. Where some pages are packed with text, others are left with large, awkward, empty spaces-not unlike the blank areas found on many maps from the Age of Exploration! Of course, there is no need to fill these gaps with sea monsters, but the space could definitely have been used to add more map details, cartouches, symbols, or curiosities. Another problem, common to many other books with large illustrations, is that the maps are not adjusted to the page size. Frequently, the images are printed over the inside margin and across the gutter so that map details are lost in the crease, and the maps appear chopped or truncated, thus considerably spoiling the visual experience. For her 2012 book, Mapping the Nation, Schulten offered zoomable, high-resolution copies of all maps on a companion website, mappingthenation.com. Readers of $A$ History of America in $100 \mathrm{Maps}$, however, only have access to 15 map thumbnails on the publisher's promotion page, america100maps.com.

In summary, Schulten does exactly what she promises at the beginning of her book: provide a visual tour through American history, supported by maps. History, in this case, is not written with a capital $\mathrm{H}$, but is instead conceived as a collection of individual stories, with each map having its own to tell. Reading $A$ History of America in 100 Maps is certainly a nice way to learn about the United States of America's past and the fascinating parts mapmaking has played in that history.

\section{REFERENCES}

Baynton-Williams, Ashley. 2015. The Curious Map Book. Chicago: University of Chicago Press.

Brooke-Hitching, Edward. 2018. The Phantom Atlas: The Greatest Myths, Blunders and Lies on Maps. San Francisco: Chronicle Books.

Harley, J. B. 1990. "Text and Context in the Interpretation of Early Maps." In From Sea Charts to Satellite Images: Interpreting North American History Through Maps, edited by David Buisseret, 3-15.

Chicago: University of Chicago Press.

Howells, Tom, and Duncan McCorquodale, eds. 2010. Mapping America. Exploring the Continent. London: Black Dog Publishing.

Mason, Betsy, and Greg Miller. 2018. All Over the Map: A Cartographic Odyssey. Washington, DC: National Geographic.

Robinson, Anthony. 2019. "Elements of Viral Cartography." Cartography and Geographic Information Science 46 (4): 293-310. doi: 10.1080/15230406.2018.1484304.

Schwartz, Seymour, and Ralph Ehrenberg. 1980. The Mapping of America. New York: Harry N. Abrams.

Schulten, Susan. 2001. The Geographical Imagination in America, 1880-1950. Chicago: University of Chicago Press.

Schulten, Susan. 2012. Mapping the Nation: History and Cartography in Nineteenth-Century America. Chicago: University of Chicago Press.

Smithsonian Institution. 2018. History of the World Map by Map. New York: DK Publishing.

\section{GIS TUTORIAL FOR CRIME ANALYSIS, SECOND EDITION}

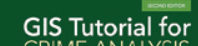

GIS Tutorial for
CRIME ANALYSIS

: $2.0 \%$

ini

anos

By Wilpen L. Gorr, Kristen S. Kurland, and Zan M. Dodson

Esri Press, 2018

348 pages, $\$ 84.99$, soft cover.

ISBN: 978-1-58948-516-7

Review by: Janet Tennent, Montgomery College
GIS Tutorial for Crime Analysis is a workbook designed for use by police forces interested in leveraging the power of GIS in various aspects of their work. Through the use of such tools, police organizations can turn raw data into useful information products, mapping incident reports, crime statistics, and modeled prediction scenarios. Analysis of the locations where crimes have occurred, and where contributing conditions and phenomena intersect, can lead to 